\title{
Polymorphic Genes for Kinin Receptors, Nephropathy and Blood Pressure in Type 2 Diabetic Patients
}

\author{
Marcin J . Zychma J anusz Gumprecht Wanda Trautsolt Ilona Szydlowska \\ Wladyslaw Grzeszczak \\ Department of Internal Medicine, Diabetology and Nephrology, Silesian School of Medicine, Zabrze, Poland
}

\section{Key Words \\ Kinin receptors - Gene - Polymorphisms . \\ Type 2 diabetes $\cdot$ Nephropathy $\cdot$ Blood pressure}

\begin{abstract}
Background/Aims: There is evidence that hereditary predisposition contributes to the development of diabetic nephropathy and hypertension. Polymorphisms in the genes for bradykinin receptors $\left(B_{1} R\right.$ and $B_{2} R$ ) were found to be associated with decreased risk of the development of end-stage renal disease. This study examines whether $B_{1} R G^{-699} C$ and $B_{2} R C^{181} T$ polymorphisms are associated with microalbuminuria or overt nephropathy, or blood pressure variation in type 2 diabetic subjects. Methods: $B_{1} R$ and $B_{2} R$ polymorphisms were determined in 153 type 2 diabetic patients with microalbuminuria, 132 with overt nephropathy (macroalbuminuria or chronic renal failure), and 161 patients with normoalbuminuria despite diabetes duration longer than 10 years. Results: Distributions of the examined polymorphisms did not differ between patients with microalbuminuria or overt nephropathy, compared to normoalbuminuric control subjects. Patients carrying the $B_{2} R T$ allele had lower DBP, compared with non-carriers: $83.6 \pm 12.0$ vs. $87.4 \pm$
\end{abstract}

$12.1 \mathrm{~mm} \mathrm{Hg}, \mathrm{p}<0.05$. Among patients not receiving $A C E l$, both SBP and DBP was significantly lower in $B_{2} R T$ allele carriers, compared to non-carriers (137.2 \pm 20.3 vs. $146.5 \pm 21.7 \mathrm{~mm} \mathrm{Hg}$, and $80.3 \pm 11.9$ vs. $85.8 \pm$ $11.6 \mathrm{~mm} \mathrm{Hg}, \mathrm{p}<0.05)$. Conclusions: Examined polymorphisms are not associated with the increased risk of incipient or overt nephropathy in type 2 diabetic patients. $\mathrm{B}_{2} \mathrm{R} \mathrm{C}^{181} \mathrm{~T}$ polymorphism may contribute to blood pressure variation in these subjects.

Copyright @2003S. Karger AG, Basel

\section{Introduction}

Development of kidney disease in diabetic patients depends on the presence of hyperglycemia, together with several superimposing environmental and hereditary factors $[1,2]$. On the other hand, predisposition to diabetic nephropathy is closely linked to hypertension [3, 4]. Also, raised blood pressure contributes substantially to faster rate of progression of renal disease, in diabetic as well as in non-diabetic subjects [5-8].

Recent studies provided evidence for a key role of the kallikrein-kinin system in blood pressure homeostasis [9]. Kinin peptides, acting via $B_{1}$ and $B_{2}$ receptors were shown

\section{KARGER}

Fax + 41613061234 E-Mail karger@karger.ch www. karger.com
Marcin J. Zychma, MD, PhD

Department of Internal Medicine, Diabetology and Nephrology Silesian School of Medicine

3-Maja 13-15, PL-41-800 Zabrze (Poland)

Tel. +48 3227125 11, Fax +48 3227146 17, E-Mail zychma@post.pl 
to have a protective role against salt-induced hypertension [10-15], and to express nephroprotective effect [1618]. The $B_{2}$ receptor $\left(B_{2} R\right)$ is a mediator of most physiological actions of bradykinins, including natriuresis, vasodilatation, increased production of eicosanoids and nitric oxide. The expression of the $B_{1}$ receptor $\left(B_{1} R\right)$ is generally absent in normal conditions, but rapidly increases after tissue injury, under the stimulation of cytokines and growth factors [9, 19]. While angiotensin I-converting enzyme inhibitors (ACEI) are known as slowing the progression of diabetic nephropathy [20,21], it has been demonstrated that ACEI action is, at least in part, a result of their ability to decrease degradation of kinins [22-24].

Thus, it has been postulated that sequence variants of the genes encoding for kinin receptors might determine different response of the kidney to various types of tissue injury, either as a $B_{2}$ receptor-mediated, blood pressure dependent effect, or under $\mathrm{B}_{1}$ receptor-dependent mechanism of different reaction to cytokine stimulation. Recently, evidence for a relationship between sequence differences in the genes encoding for kinin receptors and the development of end-stage renal disease (ESRD) has surfaced from both case-control, and family-based association studies $[25,26]$. In the present study, we report the results of association analysis between polymorphic markers in the genes encoding for kinin receptors: $\mathrm{G}^{-699} \rightarrow \mathrm{C}$ substitution in the promoter region of the $\mathrm{B}_{1} \mathrm{R}$ gene, and $\mathrm{C}^{181} \rightarrow \mathrm{T}$ transition in exon 2 of the $\mathrm{B}_{2} \mathrm{R}$ gene, with different stages of diabetic kidney disease, and blood pressure variation in patients with type 2 (non-insulindependent) diabetes mellitus.

\section{Methods}

Detailed method of collecting patients for the study was described elsewhere [27]. Briefly, 1,270 patients with type 2 diabetes were screened for microalbuminuria with dipstick MICRAL II test (Boehringer Mannheim), with subsequent verification of renal status according to repeated measurements of urinary albumin/creatinine ratio and careful review of medical files in all dipstick-positive, and in dipstick-negative patients with diabetes duration of at least 10 years (patients with previously documented persistent proteinuria or persistent raise in serum creatinine were included into the overt nephropathy group without further determination of microalbuminuria). Of the initial study 'screening group', we selected 132 patients with overt nephropathy, including 46 patients with chronic renal failure (among them 23 patients undergoing dialysis), 155 patients with microalbuminuria, and 163 normoalbuminuric subjects with known diabetes duration of at least 10 years. Hypertension was diagnosed, if patients were receiving antihypertensive treatment, or systolic or diastolic blood pressure taken at the time of microalbuminuria screening, or at time of examination of patients with previously determined overt proteinuria, and during a subsequent visit in the clinic was $\geq 140$ or $90 \mathrm{~mm} \mathrm{Hg}$ (blood pressure was measured twice with a mercurium sphygmomanometer, in the supine position, after at least $10 \mathrm{~min}$ of rest, and the results were averaged). All participants of the study were Caucasians, and gave written informed consent. The study protocol was approved by the appropriate Ethics Board.

From each patient, DNA was isolated from peripheral blood leucocytes. $B_{1} R$ gene $G^{-699} \rightarrow C$ substitution in the promoter region, as well as the $\mathrm{B}_{2} \mathrm{R}$ gene $\mathrm{C}^{181} \rightarrow \mathrm{T}$ transition in exon 2 were determined according to previously described protocols [26]. In 6 patients, genotypes were not determined due to technical problems with DNA quality.

Continuous variables were compared using either ANOVA and the post-hoc Sheffé test or Student's $t$ test. A $\chi^{2}$ test was used for comparisons of frequencies. Multiple linear regression was used to assess the association of various putative hypertension promoters to actual blood pressure values.

\section{Results}

Clinical characteristics of the study patients are given in table 1. Positive family history of hypertension in at least one parent was reported by $19.5 \%$ of the study patients, while positive history of type 2 diabetes - by $31.7 \%$ of patients.

Distributions of the examined $B_{1} R G^{-699} C$ and $B_{2} R$ $\mathrm{C}^{181} \mathrm{~T}$ genotypes in microalbuminuria and overt nephropathy groups did not differ from the control group of normoalbuminuric subjects (table 2). When both groups of microalbuminuric and overt proteinuric patients were analyzed jointly, still no deviation in genotype distributions was present (data not shown). Distributions of the examined polymorphisms were similar among type 2 diabetic patients stratified according to hypertension status: frequencies of the $\mathrm{B}_{1} \mathrm{R} \mathrm{C}$ allele carriers were $23.2 \%$ and $21.8 \%, \mathrm{~B}_{2} \mathrm{R} \mathrm{T}$ allele carriers $-15.5 \%$ and $12.0 \%$ for normotensive and hypertensive individuals, respectively. In the overall group of type 2 diabetic patients with determined $B_{1} R$ and $B_{2} R$ genotypes and included into the study groups (regardless of hypertension status), carriers of the $\mathrm{B}_{2} \mathrm{R}$ T allele had significantly lower actual diastolic blood pressure (taken at the time of microalbuminuria screening), compared with non-carriers: $83.6 \pm 12.0$ vs. $87.4 \pm 12.1 \mathrm{~mm} \mathrm{Hg}, \mathrm{p}<0.05$. Observed difference in systolic blood pressure: $145.6 \pm 22.4$ versus $150.3 \pm$ $21.6 \mathrm{~mm} \mathrm{Hg}$ ( $\mathrm{T}$ allele carriers versus non-carriers, respectively), did not reach statistical significance. Among 250 patients not receiving ACEI, both systolic and diastolic blood pressure was significantly lower in $32 \mathrm{~B}_{2} \mathrm{R}$ T allele carriers, compared to 218 non-carriers (137.2 \pm 20.3 vs. $146.5 \pm 21.7 \mathrm{~mm} \mathrm{Hg}$, and $80.3 \pm 11.9$ vs. $85.8 \pm$ $11.6 \mathrm{~mm} \mathrm{Hg}, \mathrm{p}<0.05)$. Not surprisingly, patients on 
Table 1. Selected clinical characteristics of the study groups

\begin{tabular}{lllc}
\hline & $\begin{array}{l}\text { Normoalbuminuria } \\
\text { diabetes duration } \\
\geq 10 \text { years }\end{array}$ & $\begin{array}{l}\text { Micro- } \\
\text { albuminuria }\end{array}$ & $\begin{array}{l}\text { Overt } \\
\text { proteinuria } \\
\text { and CRF }\end{array}$ \\
\hline $\mathrm{n}$ & 163 & 155 & 132 \\
Age at examination, years & $64.3 \pm 7.8$ & $62.0 \pm 8.2^{\mathrm{a}}$ & $62.0 \pm 8.9$ \\
Age at diagnosis of diabetes, years & $48.5 \pm 9.4$ & $49.7 \pm 12.3$ & $50.8 \pm 10.3$ \\
Known diabetes duration, years & $15.8 \pm 5.5^{\mathrm{b}}$ & $11.2 \pm 6.8$ & $11.2 \pm 7.0$ \\
Body mass index, $\mathrm{kg} / \mathrm{m}^{2}$ & $29.3 \pm 4.5$ & $29.9 \pm 4.3$ & $29.0 \pm 4.3$ \\
HbA1c, \% & $8.9 \pm 1.7$ & $9.2 \pm 1.7^{\mathrm{c}}$ & $8.4^{\mathrm{c}}$ \\
Hypertension, \% & 51.8 & 62.8 & $79.6^{\mathrm{d}}$ \\
Retinopathy, \% & & & 61.6 \\
$\quad$ Any & 54.2 & 49.7 & 40.7 \\
$\quad$ Background & 49.7 & 41.4 & $20.9^{\mathrm{e}}$ \\
$\quad$ Preproliferative/proliferative & 4.5 & 8.3 & \\
\hline
\end{tabular}

$\mathrm{CRF}=$ Chronic renal failure

${ }^{a} \mathrm{p}<0.05$, vs. normoalbuminuria; ${ }^{\mathrm{b}} \mathrm{p}<0.001$, vs. microalbuminuria and overt proteinuria/CRF; ${ }^{\mathrm{p}} \mathrm{p}<0.01$, vs. overt proteinuria/CRF; ${ }^{\mathrm{d}} \mathrm{p}<0.05$, vs. microalbuminuria, $\mathrm{p}<0.01$, vs. normoalbuminuria; ${ }^{\mathrm{e}} \mathrm{p}<0.05$, vs. microalbuminuria, $\mathrm{p}<0.001$, vs. normoalbuminuria.

\begin{tabular}{|c|c|c|c|c|c|c|}
\hline & \multicolumn{2}{|c|}{$\begin{array}{l}\text { Normoalbuminuria } \\
\text { diabetes duration } \\
\geq 10 \text { years }\end{array}$} & \multicolumn{2}{|c|}{ Microalbuminuria } & \multicolumn{2}{|c|}{ Proteinuria/CRF } \\
\hline & $\%$ & $\mathrm{n}$ & $\%$ & $\mathrm{n}$ & $\%$ & $\mathrm{n}$ \\
\hline \multicolumn{7}{|c|}{ B1R G-699C } \\
\hline GG & 78.3 & 126 & 78.5 & 120 & 73.9 & 96 \\
\hline $\mathrm{GC}$ & 18.6 & 30 & 20.3 & 31 & 24.6 & 32 \\
\hline $\mathrm{CC}$ & 3.1 & 5 & 1.3 & 2 & 1.5 & 2 \\
\hline \multicolumn{7}{|c|}{ B2R C181T } \\
\hline $\mathrm{CC}$ & 87.0 & 140 & 83.7 & 128 & 90.0 & 117 \\
\hline $\mathrm{CT}$ & 13.0 & 21 & 15.7 & 24 & 10.0 & 13 \\
\hline TT & 0 & 0 & 0.6 & 1 & 0 & 0 \\
\hline
\end{tabular}

Table 2. Frequencies of B1R G-699C and B2R C181T genotypes in the study groups
ACEI treatment had higher blood pressure values, compared to those without ACEI (156.4 \pm 20.0 vs. $145.2 \pm$ $22.0 \mathrm{~mm} \mathrm{Hg}$, and $89.6 \pm 12.4$ vs. $85.0 \pm 11.9 \mathrm{~mm} \mathrm{Hg}$, SBP and DBP, respectively). The presence of the $\mathrm{B}_{2} \mathrm{R} T$ allele was also independently associated with diastolic blood pressure, when accounted for renal status, body mass index, diabetes duration and glycemic control, $(\mathrm{p}<$ 0.01 ). There was no association between the systolic or diastolic blood pressure and the $\mathrm{B}_{1} \mathrm{R}$ polymorphism (data not shown).

\section{Discussion}

Recently, two studies revealed an association between the $\mathrm{B}_{1} \mathrm{R}{ }^{-699} \mathrm{C}$ allele and decreased risk of ESRD, which was demonstrated as lower $\mathrm{C}$ allele frequency, or diminished $\mathrm{C}$ allele transmission from heterozygous parents to patients affected with ESRD $[25,26]$. In these studies, proportion of patients with diabetic nephropathy was 10.5 and $19 \%$, respectively, thus giving insufficient numbers of subjects to assess the magnitude of impact of the $\mathrm{C}$ allele on the risk of ESRD in diabetic patients. In the present study, aimed on type 2 diabetic patients with microalbuminuria or overt nephropathy, no association similar to that previously observed in ESRD patients was 
demonstrated. However, the relatively small number of type 2 diabetic patients with chronic renal failure included into the overt nephropathy group did not allow us to completely exclude any minor impact of $B_{1} R$ polymorphism on progression to most advanced stages of diabetic nephropathy.

In case of $\mathrm{B}_{2} \mathrm{R}$ exon 2 polymorphism, previous reports demonstrated significantly diminished transmission of the ${ }^{181} \mathrm{~T}$ allele to offspring affected with ESRD [26], with only minor decrease in its frequency in ESRD patients compared to healthy control subjects [25]. The present analysis revealed no differences in the distributions of this polymorphism in type 2 diabetic patients stratified according to the stage of diabetic nephropathy, or the presence or absence of hypertension. On the other hand, carriers of the ${ }^{181} \mathrm{~T}$ 'protective' allele had lower actual blood pressure values, taken at the time of examination, compared to non-carriers, and the effect was even more profound, when patients with possibly confounding impact of treatment with ACEI were excluded from the analysis. However, several limitations of this analysis should be mentioned: Firstly, the effect of response to antihypertensive treatment other than ACEI, different in ${ }^{181} \mathrm{~T}$ allele carriers and non-carriers, however unlikely, cannot be completely ruled out. Secondly, biased sampling of patients for the analysis might have occurred. Such selection bias, for instance associated with the exclusion of normoalbuminuric patients with type 2 diabetes duration shorter then 10 years from the study group, or resulting from the 'cardiovascular survival effect' of the examined polymorphism should also be considered. Lastly, only one blood pressure measurement performed in controlled conditions was available for most of our patients, which contributed to a large variation of blood pressure levels in our examined group. Anyhow, such issues can only be completely resolved by a prospective, observational study, focused on repeated blood pressure measurements in an unselected population of diabetic patients, with careful consideration of antihypertensive treatment and survival.

By which mechanisms would molecular variants of the genes encoding for kinin receptors modify the risk of ESRD, or other 'cardiovascular phenotypes' (e.g. blood pressure values), is yet unclear. Previous functional experiments have determined that the presence of the $B_{1} R$ promoter ${ }^{-699} \mathrm{C}$ allele is associated with higher transcriptional promoter activity [25]. Whether this sequence difference may also cause a different magnitude of the $B_{1} R$ overexpression in response to tissue injury or in recently observed $B_{1} R$ upregulation in animal models of hyperten- sion or $\mathrm{B}_{2} \mathrm{R}$ knockout [28] remains to be determined. Interestingly, it was demonstrated that in the absence of the $B_{2}$ receptor, the $B_{1} R$ assumes some of the hemodynamic properties of the $B_{2} R$ [28].

Functional significance of the $\mathrm{B}_{2} \mathrm{R} \mathrm{Arg}^{14} \rightarrow \mathrm{Cys}$ exchange in the N-terminal extracellular domain caused by the $\mathrm{C}^{181} \mathrm{~T}$ substitution is still unclear. The N-terminal domain can be truncated without the apparent loss of function by the receptor [29], which, however, does not exclude any functional alteration associated with $\mathrm{Arg} \rightarrow \mathrm{Cys}$ substitution. Moreover, the $\mathrm{C}^{181} \mathrm{~T}$ polymorphism was shown to selectively influence the bradykinininduced contractility of the human umbilical vein, which may, for instance, suggest an altered affinity of the polymorphic extracellular domain of the receptor [30].

Genes encoding for bradykinin receptors were also studied as candidates that might influence the risk of development of hypertension. The $\mathrm{B}_{2} \mathrm{R}$ promoter ${ }^{-58} \mathrm{C}$ allele was found to be associated with hypertension in populations of Japanese and African-Americans [31, 32], but no positive association with other examined sequence differences in bradykinin receptor genes was detected. On the other hand, in a study based on Caucasian tissue donors, this $\mathrm{B}_{2} \mathrm{R}$ promoter polymorphism exerted no effect on contractile response of the umbilical vein to kinins [30], even though previous experiments have suggested its influence on transcriptional activity [33, 34]. Interestingly, in a recent study of 49 type 1 and 112 type 2 diabetic patients, a polymorphic variant located in exon 1 of the $\mathrm{B}_{2} \mathrm{R}$ gene was associated with increased urinary albumin to creatinine ratio and serum creatinine levels [35].

In summary, our study demonstrated no relationship between polymorphisms in the genes encoding for kinin receptors: $B_{1} R G^{-699} C$ and $B_{2} R C^{181} T$, and the presence of incipient or overt nephropathy in Caucasian type 2 diabetic patients. However, in our examined population of type 2 diabetic patients, the $\mathrm{B}_{2} \mathrm{R}{ }^{181} \mathrm{~T}$ allele was associated with significantly lower systolic and diastolic blood pressure. Certainly, our results obtained in a relatively small group should be replicated in larger samples of diabetic patients, and, moreover, cannot be generalized to a population of non-diabetic patients. Also, further studies of several markers from the bradykinin receptors genes, with estimations of linkage disequilibrium between the examined loci, as well as combining the examined polymorphisms into haplotypes should on one hand give us more power to detect marker-phenotype association, while on the other, could lead us to determination of target loci for subsequent functional experiments. 


\section{References}

1 Parving $\mathrm{HH}$ : Renoprotection in diabetes: Genetic and non-genetic risk factors and treatment. Diabetologia 1998;41:745-759.

2 Fogarty DG, Krolewski AS: Genetic susceptibility and the role of hypertension in diabetic nephropathy. Curr Opin Nephrol Hypertens 1997;6:184-191.

3 Viberti GC, Keen H, Wiseman MJ: Raised arterial pressure in parents of proteinuric insulin dependent diabetics. Br Med J 1987;295: 515-517.

4 Krolewski AS, Canessa M, Warram JH, Laffel LM, Christlieb AR, Knowler WC, Rand LI: Predisposition to hypertension and susceptibility to renal disease in insulin-dependent diabetes mellitus. N Engl J Med 1989;318:140145.

5 Microalbuminuria Collaborative Study Group UK: Risk factors for development of microalbuminuria in insulin dependent diabetic patients: a cohort study. Br Med J 1993;306: 1235-1239.

6 Gall MA, Nielsen FS, Smidt UM, Parving HH: The course of kidney function in type 2 (noninsulin dependent) diabetic patients with diabetic nephropathy. Diabetologia 1993;36: 1071-1078.

7 Lee ET, Lee VS, Lu M, Lee JS, Russell D, Yeh $\mathrm{J}$ : Incidence of renal failure in NIDDM. The Oklahoma Indian Diabetes Study. Diabetes 1994;43:572-579.

8 Marcantoni C, Jafar TH, Oldrizzi L, Levey AS, Maschio G: The role of systemic hypertension in the progression of nondiabetic renal disease. Kidney Int 2000;57(suppl 75):S44-S48.

9 Margolius HS: Some unanswered questions about system characteristics and roles in human disease. Hypertension 1995;26:221-229.

10 Alfie ME, Yang XP, Hess F, Carretero OA: Salt-sensitive hypertension in bradykinin $\mathrm{B}_{2}$ receptor knockout mice. Biochem Biophys Res Commun 1996;224:625-630.

11 Alfie ME, Sigmon DH, Pomposiello SI and Carretero OA: Effect of high salt intake to mutant mice lacking bradykinin $\mathrm{B}_{2}$ receptors. Hypertension 1997;29:483-487.

12 Wang DZ, Chao L, Chao J: Hypotension in transgenic mice overexpressing human bradykinin $\mathrm{B}_{2}$ receptor. Hypertension 1997;29:488493.

13 Madeddu P, Varoni MV, Palomba D, Emanueli C, Demontis MP, Glorioso N, Dessi-Fulgheri P, Sarzani R, Anania V: Cardiovascular phenotype of a mouse strain with disruption of bradykinin $B_{2}$-receptor gene. Circulation 1997;96: 3570-3578.
14 Madeddu P, Milia AF, Salis MB, Gaspa L, Gross W, Lippoldt A, Emanueli C: Renovascular hypertension in bradykinin $\mathrm{B}_{2}$-receptor knockout mice. Hypertension 1998;32:503509.

15 Mukai H, Fitzgibbon WR, Ploth DW, Margolius HS: Effect of chronic bradykinin $\mathrm{B}_{2}$ receptor blockade on blood pressure of conscious Dahl salt-resistant rats. Br J Pharmacol 1998; 124:197-205.

16 Hutchison FN, Martin VI: Effects of modulation of renal kallikrein-kinin system in the nephrotic syndrome. Am J Physiol 1990;258: F1237-F1244.

17 Hutchison FN, Webster SK, Jaffa AA: Altered renal kallikrein and renin gene expression in nephrotic rats and modulation by converting enzyme inhibition. J Clin Invest 1993;92: 1073-1079.

18 Uehara Y, Hirawa N, Numabe A, Kawabata Y, Ikeda T, Gomi T, Gotoh A, Omata M: Longterm infusion of kallikrein attenuates renal injury in Dahl salt-sensitive rats. Am J Hypertens 1997; 10:83S-88S.

19 Marceau F, Hess JF, Bachvarov DR: The B receptors for kinins. Pharmacol Rev 1998;50: 357-386.

20 The Microalbuminuria Captopril Study Group: Captopril reduces the risk of nephropathy in IDDM patients with microalbuminuria. Diabetologia 1996;39:587-593.

21 Ravid M, Savin H, Jutrin I, Bental T, Katz B, Lishner M: Long-term stabilizing effect of angiotensin-converting enzyme inhibition on plasma creatinine and on proteinuria in normotensive type II diabetic patients. Ann Intern Med 1993;118:577-581.

22 Tanaka R, Kon V, Yoshioka T, Ichikawa I, Fogo A: Angiotensin converting enzyme inhibitor modulates glomerular function and structure by distinct mechanisms. Kidney Int 1994; 45:537-543.

23 Hutchison FN, Cui X, Webster SK: The antiproteinuric action of angiotensin-converting enzyme is dependent on kinin. J Am Soc Nephrol 1995;6:1216-1222.

24 Gainer JV, Morrow JD, Loveland A, King DJ, Brown NJ: Effect of bradykinin-receptor blockade on the response to angiotensin-convertingenzyme inhibitor in normotensive and hypertensive subjects. N Engl J Med 1998;339:12851292.

25 Bachvarov DR, Landry M, Pelletier I, Chevrette $\mathrm{M}$, Betard $\mathrm{C}$, Houde I, Bergeron J, Lebel M, Marceau F: Characterization of two polymorphic sites in the human kinin $\mathrm{B}_{1}$ receptor gene: Altered frequency of an allele in patients with a history of end-stage renal failure. J Am Soc Nephrol 1998;9:598-604.
26 Zychma MJ, Gumprecht J, Zukowska-Szczechowska E, Grzeszczak W, the End-Stage Renal Disease Study Group: Polymorphisms in the genes encoding for human kinin receptors and the risk of end-stage renal failure: Results of transmission/disequilibrium test. J Am Soc Nephrol 1999;10:2120-2124.

27 Zychma MJ, Zukowska-Szczechowska E, Ossowska-Szymkowicz I, Trautsolt W, Grzeszczak W: G-protein $\beta_{3}$ subunit C825T variant, nephropathy and hypertension in patients with type 2 (non-insulin-dependent) diabetes mellitus. Am J Nephrol 2000;20:305-310.

28 Duka I, Kintsurashvili E, Gavras I, Johns C, Bresnahan M, Gavras H: Vasoactive potential of the $\mathrm{B}_{1}$ bradykinin receptor in normotension and hypertension. Circ Res 2001;16:275-281.

29 Abd Alla S, Quitterer U, Schröder C, Blaukat A, Horstmeyer A, Dedio J, Reiländer H, Müller-Esterl W: On the structure of the amino-terminal domain ED1 of the $\mathrm{B}_{2}$ receptor. Immunopharmacology 1996;33:42-45.

30 Houle S, Landry M, Audet R, Bouthillier J, Bachvarov DR, Marceau F: Affect of allelic polymorphism of the $\mathrm{B}_{1}$ and $\mathrm{B}_{2}$ receptor genes on the contractile responses of the human umbilical vein to kinins. J Pharmacol Exp Ther 2000;294:45-51.

31 Mukae S, Aoki S, Itoh S, Nishio K, Iwata T, Ueda H, Geshi E, Fuzimaki T, Katagiri T: Promoter polymorphism of the $\mathrm{B}_{2}$ bradykinin receptor gene is associated with essential hypertension. Jpn Circ J 1999;63:759-762.

32 Gainer JV, Brown NJ, Bachvarova M, Bastien L, Maltais I, Marceau F, Bachvarov DR: Altered frequency of a promoter polymorphism of the kinin $\mathrm{B}_{2}$ receptor gene in hypertensive African-Americans. Am J Hypertens 2000;13: 1268-1273

33 Braun A, Maier E, Kammerer S, Müller B, Roscher AA: A novel sequence polymorphism in the promoter region of the human $\mathrm{B}_{2}$-bradykinin receptor gene. Hum Genet 1996;97:688689.

34 Erdmann J, Hegemann N, Weidemann A, Kallisch H, Hummel M, Hetzer R, Fleck E, RegitzZagrosek V: Screening the human bradykinin $\mathrm{B}_{2}$ receptor gene in patients with cardiovascular diseases: Identification of a functional mutation in the promoter and a new coding variant. Am J Med Genet 1998;80:521-525.

35 Maltais I, Bachvarova M, Maheux P, Perron P, Marceau F, Bachvarov D: Bradykinin $\mathrm{B}_{2}$ receptor gene polymorphism is associated with altered urinary albumin/creatinine values in diabetic patients. Can J Physiol Pharmacol 2002; 80:323-327. 